\title{
Newer insights into the Psychoactive and Pharmacological Properties of Datura stramonium Linn
}

\author{
Tatini Debnath $^{1 *}$ and Raja Chakraverty ${ }^{2}$ \\ ${ }^{1}$ Pharmacist under NUHM, West Bengal, India \\ ${ }^{2}$ Assistant Professor, Bengal School of Technology, India
}

Submission: October 30, 2017; Published: November 15, 2017

*Corresponding author: Tatini Debnath, Pharmacist under NUHM, A College of Pharmacy, Sugandha, Delhi Road, Hooghly- 712102, West Bengal, India, Tel: 7278442344; Email: dtatini09@gmail.com

Abstract

Datura stramonium is a widespread growing plant commonly known as Angel's trumpet and it belongs to the family Solanaceae. The plant comprises bioactive constituents like scopolamine, hyosciamine, tropane alkaloids, tannin, proteins and carbohydrates. It has hallucinogenic effects as well as medicinal properties. Traditionally it is used in cough, fever, asthama and also in skin disorder. The plant has extensive pharmacological effect mainly analgesic in action. A substantial evaluation is contributory in scientific assessment of the medicinal properties of the plant. The ethnomedicinal, phytochemical as well as toxicological works upon Datura stramonium gives a better understanding of the particular plant. The present paper highlights upon the various properties of Datura stramonium respectively.

Keywords: Datura stramonium; Ethnomedicine; Anticholinergic; Antiasthmatic; Psychoactive

\section{Introduction}

Traditionally the plant is used to treat various diseases and there is a constant search for the medicinal value of plant. Datura stramonium has both the toxic effects and medicinal uses [1]. Since inception of life humans beings use plant for different purposes like food and medicine. Still today a large number of people use different plant for different disease treatments. Datura stramonium has most important medicinal use. From the ethnomedicinal point of view it has an important medicinal value throughout the world. The leaves and seeds are used in different treatment regime.

The leaves of Datura stramonium when mixed with mustard oil it helps in treating skin disorders. The extract of flower petals is used in ear pain. Seeds are used in fever, cough, and asthma and as purgatives. Seeds are also used intoxicants for its narcotic action [2]. In folklore medicine this plant were used because of its analgesic effects in the "Old world" [3]. Datura stramonium comprises of different types of photochemical including Tannins, Saponins, Alkaloids, Glycoside Flavonoids Steroids and Phenols [4]. The bioactive components present in branches and leaves extracts consists of high anti-microbial and anti-fungal activities [5].

\section{Phytochemistry of Datura stramonium}

The toxins in Datura are tropane belladonna alkaloids, which consists of strong anticholinergic effects. These alkaloids include: hyoscine (roots); atropine (d,l-hyoscyamine) hyoscyamine (leaves, roots, seeds), and scopolamine (l-hyoscine), as well as protein and sitosterol $[6,7]$. It is reported that hyoscyamine is the predominant alkaloid in DS from the [8,9]. Thorn apple leaves contains $0.2 \%-0.45 \%$ of total alkaloids, seeds approximately $0.2 \%$.The tropane alkaloid contain a methylated nitrogen atom (N-CH3) and include the anticholinergic drugs, atropine, hyoscyamine, and scopolamine as well as the narcotic cocaine [10].

\section{Ethnomedicinal uses}

The leaves of Datura stramonium when mixed with mustard oil it becomes useful in skin disorders. Extract of flower petals helps in reducing in ear pain and seeds are mainly used as purgative, in cough, asthma and fever. Seeds are smoked since they are narcotic action [11]. Leaf paste and extract is topically used for wounds, bleedings, injuries and pains. Seeds when used in small quantity are helpful in asthma and tonsil problems. 
The extract of leaves is also used for treatment of baldness [12]. Leaves paste used externally for management of pains [13]. Datura stramonium plant commonly used as repellents and antiparasitics [14]. Fruit oil is useful in body pain [15]. Whole plant and leaf is antispasmodic and anti-inflammatory in action [16]. Green leaves are applied topically for the softening of the boils. Extract of the fruit is applied on scalp as antidandruff and for falling hairs. A drop is poured in the ear at night when in earache [17]. Paste of leaves is externally applied for skin diseases problems [18]. Dried seeds and leaves are anticholinergics and sedatives in action [19].

Seeds are capable in make somebody unconscious [20]. Conventionally it is used for cure of rheumatism and cure of the pain [21]. $75 \mathrm{gm}$ rhizomes of ginger (Zingiber officinale), $100 \mathrm{gm}$ of garlic (Allium sativum) and 85 gm of onions (Allium cepa) are macerated together to extract the juice. To the juice is added 86 gm atosh (root of an unidentified plant) and an equal amount of darmuz (arsenic), mudra shankar (unidentified chemical, possibly a chromium salt) and camphor. One powdered seed of Datura stramonium is added to the mixture along with $400 \mathrm{gm}$ of oil from seeds of Brassica campestris. The whole amount is boiled thoroughly, slightly cooled and applied to places where there is rheumatic pain. This is done 2-3 times daily till pain is cured. The is having a stimulatory effect upon the central nervous system. Since the plant is hallucinogenic causes difficulty in the cases of poisoning. The psychoactive effects are attributed due to the presence of chemical constituents like atropine and scopolamine. These causes stupor and delirium.

\section{Medicinal Uses}

Datura stramonium is used commonly as an antiasthmatics [22-24]. The extensive reported medicinal uses embarks upon the use of the dried leaves of the plant as an anti-asthmatic agent $[25,26]$. The cure for the asthma is the mixture of the seeds and leaves when taken orally as a smoke or decoction [27]. The aqueous extracts of the seeds are used in the treatment of indigestion and gastric pains [28]. Furthermore, this herbal remedy is also sometimes advised to pregnant mother having asthmatic complaints. It is used as a psychotropic, medicinal \& antispasmodic [29]. It is used for burns, ulcers, asthma, headaches, sores and sinus infection [30]. DS is used intoxicant for its central anticholinergic effects and is made easily extracted by boiling the crushed seeds. The extract has rapid onset of action and may be useful for treating of organophosphate poisoning [31]. DS is a medicinal plant with antinociceptive effect [32] antioxidant [33], hypolipidemic [34], anti-inflammatory, antirheumatoid [35], and hypoglycemic properties [36].

\section{Pharmacological properties and herb toxicity}

Datura stramonium seed extract are having analgesic effect on both chronic $\&$ acute pain which were produced by formalin and hot plate testing methods. It is probably due to the effect of alkaloid that interacts with the opioid system [37]. The entire plant is toxic, particularly the seeds and foliage. The inhibition of central and peripheral muscarinic neurotransmission leads to anticholinergic syndrome. The patient presents with flushing, dry skin, accommodation which inflicys blurred vision and photophobia, hyperpyrexia, altered mental status, urinary retention, sinus tachycardia, myoclonic jerking. Other symptoms may include agitated delirium, impaired short-term memory, disorientation, confusion, ataxia, hallucinations, psychosis, coma, seizures, respiratory failure and cardiovascular collapse [38].

An extract prepared from the seeds of the datura possess activity which is typical of a protein lectin or haemagglutinin. The extract is able of agglutinating erythrocytes from several species, and is basically non-specific with regard to human ABO blood groups [39]. Laboratory monitoring of various changes in some blood group parameters in horses intoxicated with jimsonweed was carried out in order to investigate the effects. It was evident from the experiment that the intoxication was accompanied by erythrocytosis, hyperchromaemic, neutrophilia, leukocytosis, regenerative shift, lymphocytopenia, aneosinophilia, increased haematocrit values with very low erythrocyte sedimentation rate [40]. The entire plant is toxic but the highest amount of the alkaloids is obtained from the ripe seeds [41]. They have a prolific action as competitive antagonist of acetylcholine at central and peripheral muscarinic receptor sites. Poisoning from this plant results in general paralysis of parasympathetic innervated organs. The aqueous leaf extract of datura induces oxidative stress and cytotoxicity in human cancer cell lines. Extreme toxicity has been correlated with seizures and coma, although death is rarely reported [42].

\section{Conclusion}

The various phytochemicals present in the plant are glycosides, tannin, alkaloids, scopolamine, phenol, sterols atropine, proteins, fats, lignins and carbohydrates. When extracted with water and ethanol it contains alkaloids steroids, glycosides and saponin. The analgesic and antiasthmatic activities are due to the presence of alkaloids, tannins, carbohydrates and proteins. The presence of atropine helps in the treatment of Parkinson's disease, peptic ulcers, diarrhea and bronchial asthma [43]. The extraction of D. stramonium shows insecticidal effect while ethanolic extract shows good anti-microbial activities. Conventional use of paste of leaves and extracts are topically used for wounds, bleeding injuries and pain. Extract of flower petals is used in ear pain as well as seeds are used in cough, as purgative, in cough, asthma and fever

\section{References}

1. Devi MR, Bawari M, Paul SB and Sharma GD (2011) Neurotoxin and Medicinal Properties of Datura stramonium L-Review. Assam University Journal of Science \& Technology 7(1): 139-144. 


\section{Global Journal of Addiction \& Rehabilitation Medicine}

2. Khan J, Khan R, Qureshi RA (2013) Ethnobotanical Study of Commonly Used Weeds of District Bannu, Khyber Pakhtunkhwa (Pakistan). Journal of Medicinal Plants Studies 1(2): 1-6.

3. Zargari A (1989) Medicinal Plants. ( $1^{\text {st }}$ Edn) Tehran University Press pp. 637-639.

4. Dwivedi S, Dwivedi A, Dwivedi SN (2008) Folk Lore Uses of Some Plants by the Tribes of Madhya Pradesh with Special Reference to Their Conservation. Ethnobotanical Leaflets 12: 763-771.

5. Gul H, Qaisrani RN, Khan MA, Hassan S, Younis N (2012) Antibacterial and antifungal activity of different extracts of Datura stramonium (branches and leaves sample). Journal of Biotechnology and Pharmaceutical Research 3(9): 141-148.

6. Friedman M, Levi E (1989) Composition of jimson weed (Datura stramonium) seeds. J of Agri and Food Chem 37: 998-1005.

7. Chang SS, Wu ML, Deng JF , Lee CC , Chin TF, et al. (1999) Poisoning by Datura leaves used as edible wild vegetables. Vet and Human Toxicol 41(4): 242-245.

8. Evans WC, Trease, Evans (2006) Pharmacognosy, (14 ${ }^{\text {th }}$ edn), Harcourt Brace and Company. Asia Pvt Ltd 341-43, 493, 480.

9. Oshima T, Sagara K, Tong Y, Zhan GG, Chen Y (1989) Screening methods in Pharmacology, Academic Press, New York. Chem Pharm Bull 37: 2456

10. Fan D, John J, Kriton KH (2005) Effects of glyphosate, chlorsulfuron, and methyl jasmonate on growth and alkaloid biosynthesis of Jimson weed (Datura stramonium L.). Pestic Biochem Physiol 82(1): 16-26.

11. Khan J, Khan R, Qureshi RA (2013) Ethnobotanical Study of Commonly Used Weeds of District Bannu, Khyber Pakhtunkhwa (Pakistan). Journal of Medicinal Plants Studies 1(2): 1-6.

12. Khan SW, Khatoon S (2008) Ethnobotanical studies on some useful herbs of Haramosh and Bugrote valleys in Gilgit, Northern areas of Pakistan. Pak J Bot 40(1): 43-58.

13. Njoroge GN (2012) Traditional Medicinal Plants in Two Urban Areas in Kenya (Thika and Nairobi): Diversity of traded species and conservation concerns. Ethnobotany Research \& Applications 10(9): 329-338.

14. Oseni OA, Olarinoye CO, Amoo IA (2011) Studies on chemical compositions and functional properties of thorn apple (Datura stramonium $L$ ) Solanaceae. African Journal of Food Science 5(2): 4044.

15. Vijendra N, Kumar KP (2010) Traditional knowledge on ethnomedicinal uses prevailing in tribal pockets of Chhindwara and Betul Districts, Madhya Pradesh, India. African Journal of Pharmacy and Pharmacology 4(9): 662-670.

16. Dwivedi S, Dwivedi A, Dwivedi SN (2008) Folk Lore Uses of Some Plants by the Tribes of Madhya Pradesh with Special Reference to Their Conservation. Ethnobotanical Leaflets 12(1): 763-771.

17. Shah GM, Khan MA (2008) Common Medicinal Folk Recipes of Siran Valley, Mansehra, Pakistan. Ethnobotanical Leaflets 10: 49-62.

18. Reddy BU (2009) Antimicrobial activity of Datura stramonium L. and Tylophora indica (Burm. F) Merr. Pharmacologyonline 1:1293-1300.

19. Wazir SM, Dasti AA, Shah J (2004) Common medicinal plants of Chapursan valley, Gojal II, Gilgit, Pakistan. Journal of Research (Science) 15(1): 41-43.

20. Rahmatullah M, Das AK, Mollik AH, Jahan R, Khan M, et al. (2009) An Ethnomedicinal survey of Dhamrai sub-district in Dhaka district, Bangladesh. American-Eurasian Journal of Sustainable Agriculture

\section{3(4): 881-888.}

21. Biswas KR, Khan T, Monalisa MN, Swarna A, Ishika T, et al (2011) Medicinal Plants Used by Folk Medicinal Practitioners of Four Adjoining Villages ofNarail and Jessore Districts, Bangladesh. American- Eurasian Journal of Sustainable Agriculture 5(1): 23-33.

22. Müller JL (1998) Love potions and ointment of witches: historical aspects of nightshade alkaloids. Cli Toxicol 36(6): 617-627.

23. Ertekin V, Selimoglu MA Altinkaynak SA (2005) combination of unusual presentations of Datura stramonium intoxication in a child: Rhabdomyolysis and fulminant hepatitius. J of Emergency Med 28: 227- 228.

24. De FV, Senatore F (1993) Medicinal plants and phytotherapy in the Amal Fitan Coast, Salerno province Campania, Southern Italy. J Ethnopharml 39(1): 39-51.

25. John D (1984) One hundred useful drugs of the Kani tribes of Trivandum forest divisions, Kerala, India. Inter J crude drug Res 22(1): 17-39.

26. Shaikh AL, Sablay ZM (2005) Hallucinogenic plant poisoning in children. Saudi Med J 26(1): 118-121.

27. Hirschmann GS, De Arias AR (1990) A survey of medicinal plants of Minas Gerais, Brazil. J Ethanopharm 29(2): 159-172.

28. Bhattarai NK (1993) Folk herbal medicines of Dolakha district, Nepal. Fitoterapia 64(5): 387-395.

29. Kirtikar JD, Basu BD (1994) Indian Medicinal Plants. Leader Road, Allahabad, India.

30. Mitchell SA, Ahmad MH (2006) A Review of Medicinal Plant Research at the University of the West Indies, Jamaica. West Indian Med J 55 (4): 243-269.

31. Bania TC, Chu j, Bailes D, Onelli M (2004) Jimson Weed Extract as a Protective Agent in Severe Organophosphate Toxicity. Acad Emerg Med 11(4): 335-338.

32. Abdollahi M , Karimpour H , Monsef Esfehani HR (2003) Antinociceptive effects of Teucrium polium $L$ total extract and essential oil in mouse writhing test. Pharmacol Res 48(1): 31-35.

33. Couladis M, Tzakou O, Verykokidou E, Harvala C (2003) Screening of some Greek aromatic plants for antioxidant activity. Phytother Res 17(2): 194-195.

34. Rasekh HR, Khoshnood Mansourkhani MJ, Kamalinejad M (2001) Hypolipidemic effects of Teucrium polium in rats. Fitoterapia 72(8): 937-939.

35. Tariq M, Ageel AM, Al Yahya MA, Mossa JS, Al Said MS (1989) Antiinflammatory activity of Teucrium polium. Int J Tissue React 11(4): 185-188.

36. Gharaibeh MN, Elayan HH, Salhab AS (1988) Hypoglycemic effects of Teucrium polium. J Ethnopharmacol 24(1): 93-99.

37. Khalili NM (2004) Evaluation of analgesic effect of Datura stramonium seed extract in Neurotoxin and Medicinal Properties on hot plate and formalin tested on male rats. I J med and Arom Plants 20(3): 309-322.

38. Alberto K, Claudia S, Ludmilla K, Arnon B (2001) Toxic Delirium due to Datura stramonium. Israel Med Asso J 3: 538-539.

39. Dugan GM, Gumbmann MR, Friedman M (1989) Toxicological evaluation of jimson weed (Datura stramonium) seed. Food and Chem Toxicol 27(8): 501-510. 
40. Kalpatrick DC, YeOman MM, Kipatrick SP (1978) A lectin from seed extracts of Datura stramonium. Plant Sci Lett 13(1): 35-40.

41. Binev R, Valchev I, Nikolov J (2006) Haematological studies on Jimson weed (Datura stramonium) intoxication in horses. Trakia J of Sci 4(1): 43-48.

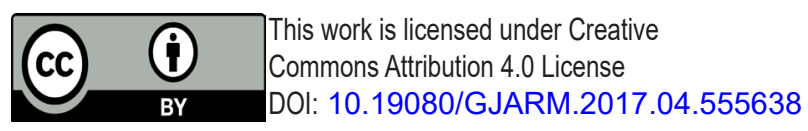

42. DeFrates L J, Hoehns JD, Sakornbut EL, Glascock DG, Tew AR (2005) Antimuscarinic intoxication resulting from the ingestion of moonflower seeds. The Annals of Pharm 39(1): 173-176.

43. Weitz G (2003) Love and death in Wagner's Tristan und Isolde. An epic anticholinergic crisis. BritishMed J 327(7429): 1469-1471.

Your next submission with Juniper Publishers will reach you the below assets

- Quality Editorial service

- Swift Peer Review

- Reprints availability

- E-prints Service

- Manuscript Podcast for convenient understanding

- Global attainment for your research

- Manuscript accessibility in different formats

( Pdf, E-pub, Full Text, Audio)

- Unceasing customer service

Track the below URL for one-step submission https://juniperpublishers.com/online-submission.php 